\title{
Foxes, people and hens: human dimensions of a conflict in a rural area of southern Chile
}

\author{
Zorros, gente y gallinas: dimensión humana de un conflicto en un área rural del sur de \\ Chile
}

EDUARDO A. SILVA-RODRÍGUEZ ${ }^{1,2, *}$, MAURICIO SOTO-GAMBOA ${ }^{3}$, GABRIEL R. ORTEGA-SOLÍS $^{1}$ \& JAIME E. JIMÉNEZ ${ }^{4}$

\author{
${ }^{1}$ Escuela de Medicina Veterinaria, Facultad de Ciencias Veterinarias, Universidad Austral de Chile, \\ Casilla 567, Valdivia, Chile \\ ${ }^{2}$ Department of Wildlife Ecology and Conservation \& School of Natural Resources and Environment, University of \\ Florida, 110 Newins-Ziegler Hall, Gainesville, FL 32611-0430, USA \\ ${ }^{3}$ Instituto de Ecología y Evolución, Facultad de Ciencias, Universidad Austral de Chile, Casilla 567, Valdivia, Chile \\ ${ }^{4}$ Laboratorio de Vida Silvestre, Universidad de Los Lagos, Casilla 933, Osorno, Chile \\ * Corresponding author: eduardosilva@ufl.edu
}

\begin{abstract}
Human-carnivore conflict has been recognized as one of the main threats to carnivore conservation. When small livestock or poultry are available, small carnivores will likely prey upon them. Centinela -a rural area located in Southern Chile where chillas (Lycalopex griseus Gray) and small farmers coexist- was chosen as a study site. To understand potential conflicts we conducted interviews to assess local knowledge, experiences, and attitudes toward this fox and small stock management. Almost a third of the interviewed people reported the loss of poultry during the last year due to chillas, which was confirmed by dietary analysis in a parallel study. Consequently, most research participants (67.4\%) had negative attitudes toward the chilla. Management appeared to be related to poultry losses, since no losses were reported when poultry was confined in henhouses, suggesting that continuous confinement was an effective measure to prevent the conflict. The negative attitudes are further reflected in that most people reported to have killed at least one chilla.
\end{abstract}

Key words: carnivore conservation, human attitudes, human-wildlife conflicts, Lycalopex griseus, subsistence farming.

\section{RESUMEN}

Los conflictos entre humanos y carnívoros han sido reconocidos como una de las mayores amenazas para la conservación de carnívoros. Cuando existe ganado menor o aves domésticas disponibles, es esperable que pequeños carnívoros depreden sobre estas. Centinela -un área rural localizada en el sur de Chile y donde coexisten zorros chilla (Lycalopex griseus Gray) y pequeños agricultores- fue escogida como área de estudio. Para entender los posibles conflictos entre agricultores y zorros, evaluamos los conocimientos locales, experiencias, y actitudes hacia este zorro, así como el manejo de los animales domésticos usando una encuesta. Casi un tercio de los encuestados reportaron la pérdida de aves domésticas en el último año como consecuencia de la depredación por parte de chillas. Estudios simultáneos de la dieta de chillas mostraron resultados coincidentes con esas denuncias. La mayoría de los participantes del estudio (67.4\%) manifestó actitudes negativas hacia la chilla. Las pérdidas de aves parecieran estar relacionadas con su manejo, debido a que ningún agricultor reportó pérdidas cuando las gallinas se encontraban encerradas en gallineros. Esto sugiere que el encierro permanente de las aves podría ser un método efectivo de prevención de las pérdidas. Las actitudes negativas se reflejaron también en el hecho de que la mayor parte de los encuestados reportó haber eliminado zorros chillas en al menos una ocasión.

Palabras clave: actitudes humanas, agricultura de subsistencia, conflictos humanos - vida silvestre, conservación de carnívoros, Lycalopex griseus. 


\section{INTRODUCTION}

Due to ecological and social reasons, carnivore conservation differs from other taxa conservation, because many of their species are perceived as a threat to human interests (Ginsberg 2001). The most common source of conflict between carnivores and humans is competition for resources, particularly predation upon domestic animals (SilleroZubiri \& Laurenson 2001, Treves \& Karanth 2003), which results in the persecution and elimination of the carnivores involved (Treves \& Karanth 2003, Woodroffe et al. 2005). As a consequence, human-carnivore conflict has resulted in the range collapse of species such as the African wild dog (Lycaon pictus Temmink) and in the extinction of the Falklands' wolf (Dusicyon australis Kerr) (Sillero-Zubiri \& Switzer 2004).

A key component of the conflict is its human dimension. In particular, the effects of the conflict on human attitudes will be affected by the vulnerability of the different stakeholders. Vulnerability is defined as the household capacity to cope with risk and is different from risk of exposure, which is common to everyone in the same locality (Treves et al. 2006). The social profiles of the individual or the community -such as low level of education, rural residence, livestock ownership, and high levels of dependence on domestic animals as a source of protein- will increase the vulnerability of the household and consequently affect negatively the attitudes toward carnivores (Kellert 1985, Kleiven et al. 2004).

A typology of basic attitudes toward animals and the natural environment had been used to describe fundamental values and meanings people attach to the nonhuman world (Kellert 1985). Among them, utilitarian attitudes must be highlighted because they prevail among farmers, which is the occupational group most frequently involved in human-carnivore conflict. Utilitarian attitudes are related to the feeling that animals must serve human purposes, and consequently should be valued depending on how they affect human welfare (Kellert 1985, Conover 2002). When carnivores conflict with people by killing livestock, game and -in the case of some big carnivores- damaging people (Sillero-Zubiri \& Laurenson 2001, Sillero-Zubiri \& Switzer 2004,
Inskip \& Zimmermann 2009), negative attitudes are likely to occur.

In spite of the high importance of understanding human-carnivore conflicts the quality of information available is highly variable, with most information concentrated in conflicts involving large species. For example, in a recent review, Inskip \& Zimmermann (2009) showed that conflict with people is well understood for eight out of ten species of large felids ( $>20 \mathrm{~kg}$ ) whereas this was the case for only one out of twenty-seven smaller species. This is despite the fact that at least twenty-one of these small to medium-sized cats are involved in some conflict with people (Inskip \& Zimmermann 2009). This disparity also seems to exist for canids: while the understanding of conflict for large species such as grey wolves (Canis lupus L.), Ethiopian wolf (Canis simensis Rüppell) and African wild dogs is relatively good (see Sillero-Zubiri \& Switzer 2004), there is little information available for issues involving small canids such as foxes. Most information available for conflicts involving small canids comes from developed countries and from only one common and widely distributed species: the red fox (Vulpes vulpes L.) (see Heydon \& Reynolds 2000, Stahl et al. 2002, Moberly et al. 2004). This situation holds for Latin American foxes where the information available is either anecdotic (Housse 1953, Greer 1965) or includes only human perceptions (Cossios 2004, Díaz 2005, Lucherini \& Merino 2008). The only exception is research done in the Argentinean Patagonia regarding the impact of culpeo foxes (Lycalopex culpaeus Mol.) on sheep production (see Novaro 1991, Travaini et al. 2000). Information regarding conflicts involving other species or socio-cultural systems is currently lacking.

The chilla fox (Lycalopex griseus Gray) is among the species that have been identified as potentially problematic in South America because they may prey upon livestock and domestic birds, and consequently it is heavily persecuted (González del Solar \& Rau 2004). Chillas are small foxes weighting 2.5 to $3.6 \mathrm{~kg}$ (Jiménez et al. 1995) and have a wide geographic distribution that includes the majority of Chile and Argentina. Due to their generalist diet, chillas will likely prey upon small livestock and poultry if they have the chance. However, aside from anecdotal accounts (Housse 1953, Greer 1965) there is 
almost no published data on the importance of the chilla as a small livestock predator, on human attitudes towards this fox, or on measures implemented to control potential chilla damage. If chillas prey on small stock or poultry, we predicted that human attitudes toward this species would be negative, and that people would take control measures to lessen the actual or perceived threat. In this paper, we examine people's behavior toward the chilla in a rural setting of southern Chile. Our objectives were to evaluate human attitudes toward the chilla in a human-dominated landscape where small livestock is available, people's perceptions about chillas, and the effectiveness of control measures implemented by locals.

\section{METHODS}

\section{Study site}

The research was carried out in Centinela $\left(40^{\circ} 14^{\prime}\right.$ $\mathrm{S} ; 7^{\circ} 04^{\prime} \mathrm{W}$ ), a rural area located $6 \mathrm{~km}$ north of the city of La Unión, Los Ríos administrative Region, southern Chile. The study site encompassed an extension of ca. 1,500 ha of small private ranches used for agriculture (mainly sheep pastures and wheat fields) and for pulp production (monocultures of exotic eucalyptus trees). Weather is template humid, with yearly average precipitations of $1,267 \mathrm{~mm}$ and a mean temperature of $11.6{ }^{\circ} \mathrm{C}$ (Luebert \& Pliscoff 2005). The landscape was composed of anthropogenic prairies interspersed with scattered scrublands, eucalyptus plantations, and patches of native forests (Silva-Rodríguez 2006). The study site is inhabited by five wild carnivores: chilla, guigna (Leopardus guigna Mol.), puma (Puma concolor L.), Molina's hog-nosed skunk (Conepatus chinga Mol.) and the exotic American mink (Neovison vison Schreber). The local conditions found at Centinela prevail in most landscapes of southern Chile.

\section{The human population studied}

The area was inhabited by 47 families totaling ca. 130 people (Silva-Rodríguez 2006). The farmers in the area -and the characteristics of the agriculture developed- resemble that of the small farmer type described by Amtmann et al. (1998) for this part of Chile. In Centinela, the farms are small, averaging 20.9 ha, there are many different types of land ownership, and families consume most of what they produce on their land. These characteristics lead to a diversification of production strategies, driving local people to cover part of their basic needs with their own production, while earning very small amounts of money, mostly in the form of sporadic work and public subsidies as pensions (Silva-Rodríguez 2006). The scarcity of resources makes social groups like this highly vulnerable to changes in productivity and adverse situations (Amtmann et al. 1998).

The high vulnerability of this subsistence system makes it highly interesting for studying human-carnivore conflicts. Given the scarcity of resources, the economic constraints faced by local people, and the importance of food production for personal consumption (Amtmann et al. 1998), poultry losses due to the foxes could be socially significant (understood as a significant damage for food security or household incomes). This may be the case even if domestic animals do not constitute a significant portion of the diet of foxes.

\section{The questionnaire}

We developed a questionnaire to evaluate both qualitative and quantitative human attitudes, knowledge, and past experiences of locals toward the chilla. We modified questionnaires applied by Díaz (2005) in southern Chile and by Dickman (2005) in Tanzania to fit the objectives of our study. The questionnaires were first tested and refined in two areas located close to our study site. The final questionnaire contained 33 questions divided in three sections (See Appendix).

We recorded the numbers and management practices (i.e., free foraging, daily foraging with night confinement, or continuous confinement) of the domestic species that could be preyed upon by chillas (e.g., hens, ducks, geese, turkeys, sheep, and goats), and documented the losses that happened during the year April 2005 to April 2006. We also evaluated the preventive and control measures used by local people to reduce chilla-induced losses. Results are presented as mean \pm 1 standard deviation.

Human attitudes toward the chilla were evaluated using three Likert-scale questions (five ordinal categories, where a score of one is 
most negative and a score of five is most positive, Babbie 1988). Likert scores were summed for each individual. Data is presented using median as measure of central tendency and interquartile range (IQR) as measure of dispersion. The attitudes of a person were considered negative if the scores summed six or less and positive if summed 12 or more (SilvaRodríguez et al. 2007).

To measure knowledge, we used both free response and multiple choice questions. We also considered anecdotic experiences and stories described by locals that complemented the answers provided by the interviewees and were important for understanding the cultural background of human-chilla conflicts, but were not considered formally as part of the questionnaire.

The questionnaire was administered between April and May 2006 in 43 of the 47 households of the area. In three of the houses we did not find people, and in one case the owner refused to respond the questionnaire. The first resident older than 18 years that opened the door was selected for interview. Prior to being asked to participate, people were given an explanation of our objectives and assured that they were free to participate and that their identities would not be disclosed. In cases where non-target people opened the door (children, visitors or others), we asked for the head of household. During all interviews, people seemed to feel comfortable without showing mistrust, even when asked about against-the-law information such as killing foxes by them. A confidentiality agreement was offered to all participants in the study.

\section{RESULTS}

\section{Characteristics of the research participants}

A hundred and thirty-nine persons lived in the 43 houses evaluated $(3.2 \pm 1.6$ people per house) at the study site. Most families (34) have lived at the study site for more than 15 years, and just four have lived there less than five years. Forty three people were interviewed, 19 of them were women. In terms of age, eight interviewees were between 20 and 39 years old (four females), 15 were between 40 and 59 (seven females), and the remaining 20 were over 60 years old (eight females). Three interviewees had never gone to school (and were illiterate), 37 had left school before finishing primary education (less than eight years of school), and the remaining three did not finish their secondary education.

\section{Ownership and management of domestic animals}

Farms had an average area of $20.9 \pm 32.2$ ha $(0.1-150.0) ; 60.1 \%$ of them were smaller than 10.0 ha. Twenty nine households were located in properties of the family of the interviewee, 13 families lived in the property of their employer, six families lived in a place lent by other people, and the remaining four either rented or lived on a parcel of land without permission. Farms were used for several different production activities, including agriculture, livestock husbandry and forestry (Table 1). The farm products were mostly for domestic consumption. Families relied mainly on one or more of the following income sources: temporary jobs (55.8\%), pensions $(39.5 \%)$, permanent employment $(23.3 \%)$ and sale of the farm's production $(20.9 \%)$.

Most farmers owned hens and sheep; fewer owned geese, which were generally kept free during the day and confined in pens during the night (Table 2). Twenty-two interviewees considered that confining animals only during the night was the better way to protect domestic animals from predators. This was in fact the most used method by locals to manage their livestock (Fig. 1). Twelve interviewees considered that permanent confinement was the best way to prevent losses, but most of them did not use that type of management, citing high costs of building the enclosure and especially of providing food. Something similar happened with the use of firearms. Although 12 persons considered that killing foxes was one of the better ways to prevent losses, only four actually used guns. This was justified by locals because, since 2005 buying ammunition required that residents had their weapons registered, which few had. Having dogs (Canis lupus familiaris L.) was also frequently mentioned as a useful measure to prevent animal losses from chillas by 17 interviewees.

\section{Predation of chillas on chicken}

Twelve out of 37 interviewed people whose properties had hens informed us that they have 
had losses due to chillas during the last year. In farms reported to be affected by foxes, the number of hens killed during the last year was $15.4 \pm 16.0$ per farm, which was equivalent to $34.5 \pm 26.6 \%$ of the hens they had. Several other domestic species were reported as killed by foxes, including ducks (nine in one farm), geese (three in one farm), turkey (six in one farm) and a lamb that according to the research participant was killed during the winter. For poultry, people could not specify the age of the attacked birds (i.e., losses were of adults and chickens). However, in the other species all losses were juvenile animals.

According to all interviewed people, chilla attacks on poultry happened during daytime, when domestic birds were free. When asked specifically about foxes getting inside of henhouses, only two persons indicated that this occurred, but none of them had had losses inside henhouses during the last year. When asked about seasonality in fox-induced losses, 19 interviewees said that most damage occurred in summer, 12 in spring, and the

TABLE 1

Production activities developed at 43 farms in Centinela and the destination of their product. $\mathrm{n}$ is the number of farms that developed a certain activity; FM, formal market (i.e. supermarkets, forestry companies, etc.); IM, informal market (sale to neighbors, street selling, etc.); SU, self-use. Note that production can have more than one purpose.

Actividades productivas llevadas a cabo en 43 predios de la localidad de Centinela y uso al cual es destinada la producción. $\mathrm{n}$ es el número de predios que desarrollan una determinada actividad; FM, corresponde al mercado formal (supermercados, empresas forestales, etc.); IM, corresponde al mercado informal (venta a vecinos, venta en la calle en la ciudad, etc.); SU, se refiere a producción destinada al consumo familiar. Es importante notar que la producción puede tener más de un posible destino.

\begin{tabular}{lcccc}
\hline & & & Use & IM \\
\cline { 2 - 5 } & $\mathrm{n}$ & FM & 0 & 2 \\
\hline Dairy & 7 & 5 & 0 & 4 \\
Beef production & 6 & 2 & 6 & 25 \\
Sheep/goat production & 25 & 2 & 2 & 37 \\
Poultry & 37 & 0 & 0 & 0 \\
Cereal & 8 & 8 & 1 & 26 \\
Potatoes & 26 & 1 & 2 & 30 \\
Vegetables & 30 & 0 & 4 & 27 \\
Fruits & 27 & 0 & 0 & 0 \\
Exotic tree plantations & 15 & 15 & 0 & 28 \\
Firewood extraction & 29 & 1 & 2 & 3 \\
Others & 5 & 1 & & \\
\hline
\end{tabular}

TABLE 2

Number of farms, mean number ( $\pm 1 \mathrm{SD})$ and type of management of domestic species that could be potentially depredated by chillas in Centinela, Chile.

Tenencia de animales domésticos que podrían ser depredados por chillas según número de predios, número medio de animales por predio $( \pm 1 \mathrm{DE})$ y forma de manejo empleada en Centinela, Chile.

\begin{tabular}{|c|c|c|c|c|c|}
\hline \multirow[t]{2}{*}{ Species } & \multirow[t]{2}{*}{ Number of farms } & \multirow{2}{*}{$\begin{array}{l}\text { Mean number of } \\
\text { animals per farm }\end{array}$} & \multicolumn{3}{|c|}{ Management (number of farms) } \\
\hline & & & $\begin{array}{l}\text { Continuous } \\
\text { foraging }\end{array}$ & $\begin{array}{c}\text { Night } \\
\text { confinement }\end{array}$ & $\begin{array}{c}\text { Continuous } \\
\text { confinement }\end{array}$ \\
\hline Sheep & 25 & $11.0 \pm 7.9$ & 2 & 23 & 0 \\
\hline Goats & 3 & $11.0 \pm 12.1$ & 1 & 2 & 0 \\
\hline Pigs & 19 & $10.0 \pm 22.8$ & 1 & 12 & 6 \\
\hline Hen & 37 & $24.0 \pm 22.1$ & 3 & 30 & 4 \\
\hline Geese & 14 & $6.6 \pm 3.3$ & 0 & 14 & 0 \\
\hline Duck & 8 & $11.0 \pm 5.9$ & 0 & 7 & 1 \\
\hline Turkey & 5 & $4.8 \pm 3.6$ & 1 & 4 & 0 \\
\hline
\end{tabular}




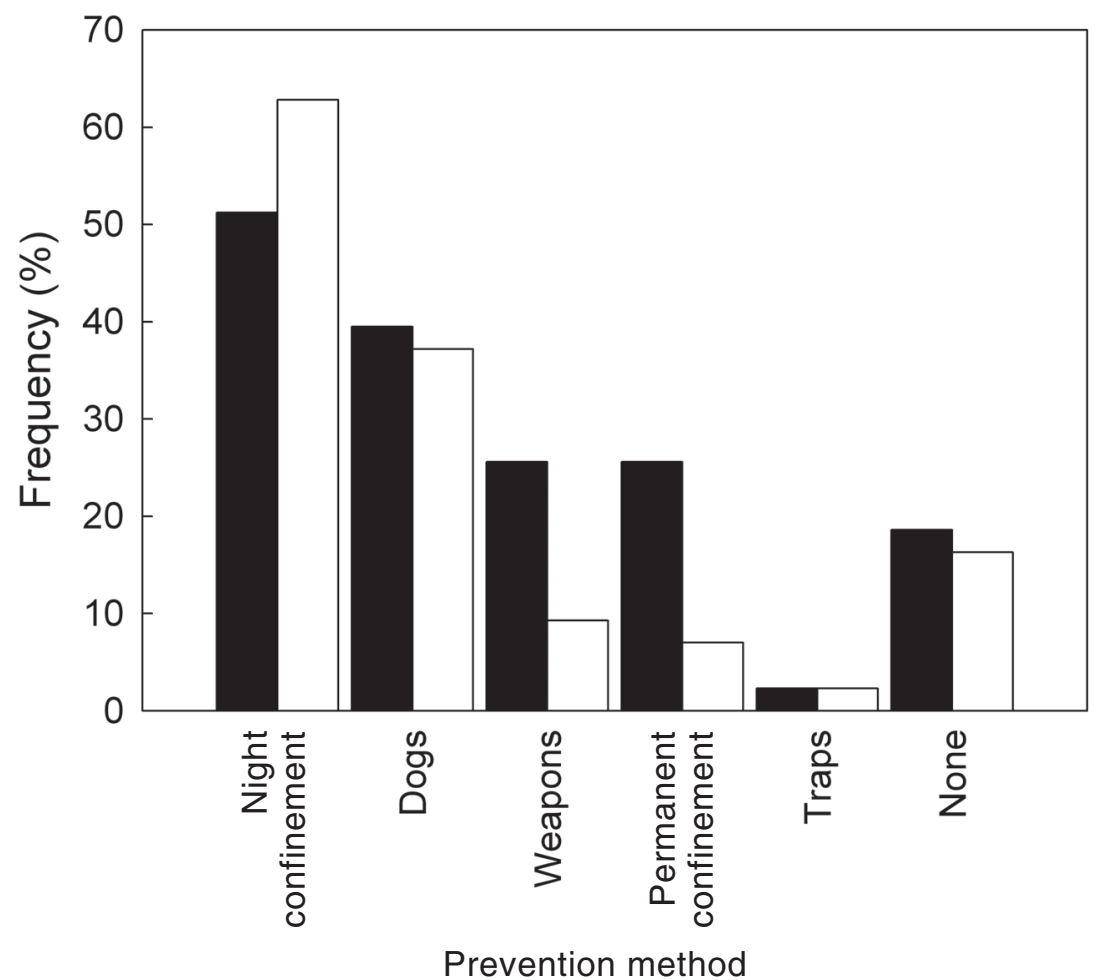

Fig. 1: Control measures to prevent losses due to predators. White columns indicate control measures actually used by local people and black columns indicate those considered to be the best.

Métodos utilizados para la prevención y control de pérdidas producidas por depredadores. Las columnas blancas indican los métodos utilizados y las columnas negras indican las medidas consideradas como más efectivas.

remaining 12 mentioned fall and winter in equal proportion. Interestingly, 22 persons out of 31 that reported that most losses occurred during spring or summer related increased damage to chillas' breeding. Most locals (36) believed that foxes get accustomed to killing domestic birds and return every day, taking one hen daily. Thirty one of the interviewees had seen a chilla with a hen in its muzzle at least once.

All interviewees but one believed that chillas killed poultry, an item that 33 persons considered to be the main prey of the fox. More than $60 \%$ considered that chillas also consumed wild birds, fruits of native terrestrial bromeliads (Greigia sphacellata (Ruiz \& Pav.) Regel), insects, exotic European hares (Lepus europaeus Pallas), domestic sheep and mice (Fig. 2). In relation to the legal status of chillas in Chile, 18 thought that fox hunting was banned, 12 claimed that foxes could be hunted only if they were producing damage, and four believed that hunting was allowed with no restriction. The remaining nine did not know the answer to that question.

\section{Attitudes toward chillas}

Most people held negative attitudes toward the chilla; they responded that they "did not like it" or "did not like it at all". Locals considered this canid a damaging species, and would prefer that chillas disappear or at least be reduced in their numbers (Table 3). Attitudes of research participants toward the chilla were mostly negative $(67.4 \%)$. Only one person manifested positive attitudes. The sum of attitudes scores tended to be smaller (i.e. more negative) among women than among men (women, median $=5.0$ $[\mathrm{IQR}=3.0-6.0]$; men, median $=6.0[\mathrm{IQR}=3.0-$ $10.0])$, and among older than younger people (20 - 40 years old, median $=6.0[\mathrm{IQR}=6.0-8.3] ; 41$ - 60 years old, median $=7.0[\mathrm{IQR}=4.0-8.5] ;>$ 60 years old, median $=5.0[\mathrm{IQR}=3.8-6.0]$ ).

Twenty three interviewees admitted to have killed at least one chilla while living in the 


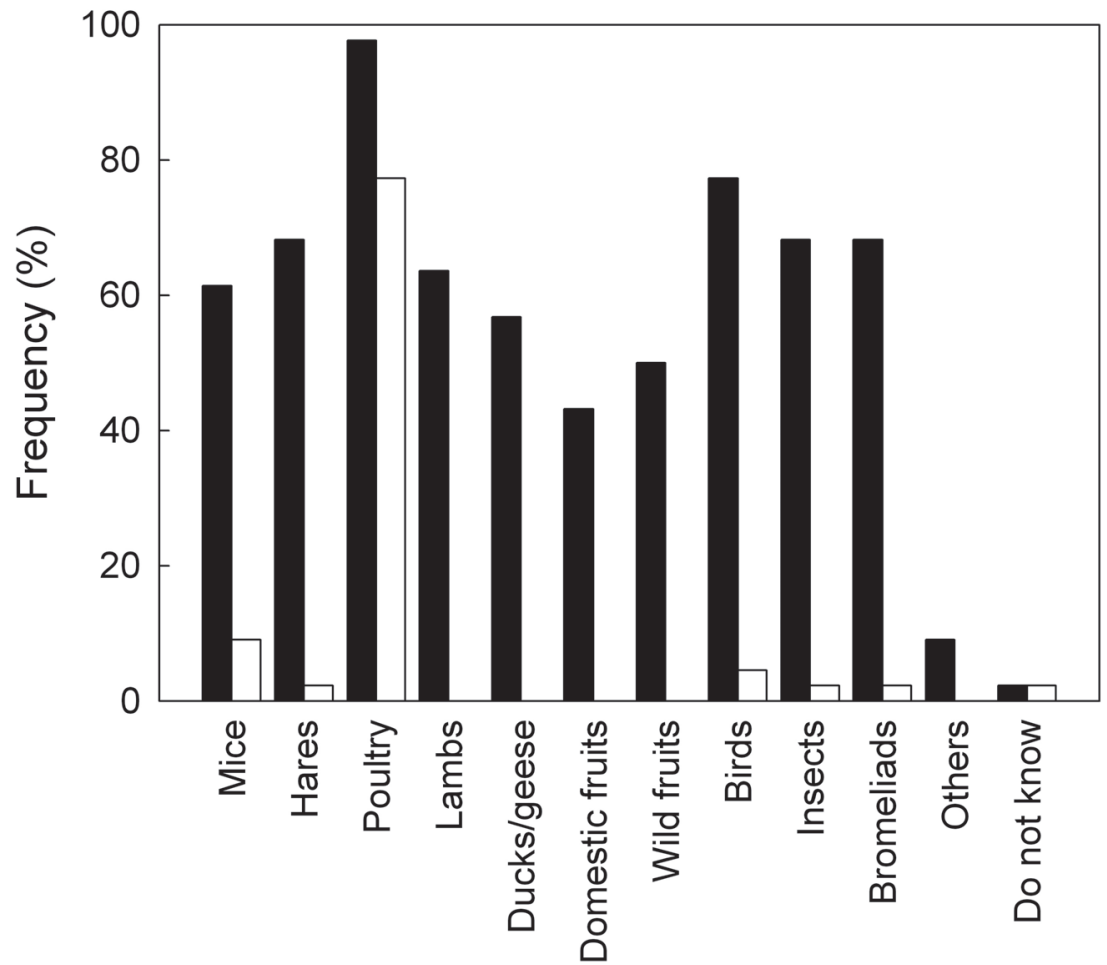

Item

Fig. 2: Items thought to be important in chilla's diet by local people in Centinela. Black columns indicate items considered to be consumed by chillas. White columns indicate items considered to be the most important in chilla's diet.

Presas consumidas por chillas de acuerdo a la percepción de los pobladores de Centinela. Las columnas blancas indican presas que los pobladores creen que las chillas consumen. Las columnas negras indican presas que los pobladores creen que son el principal alimento de las chillas.

area. Sixteen locals reported that they have killed foxes as a response to predation upon domestic animals, five mentioned accidental killing in snares whose objectives where to trap hares, and four mentioned other reasons. Six interviewees living in the study area admitted to having killed a total of eight chillas during the last year. Three of these were accidentally trapped using snares and subsequently killed (by the same person), three were chased by domestic dogs, and two were killed using firearms in response to poultry losses (Fig. 3).

\section{DISCUSSION}

\section{Human-chilla conflicts in context}

Our results confirm findings from other parts of the world, thus supporting the impression that carnivore conflicts have some central features in common. For example, there are several socio-economic factors that have been identified as shaping lower tolerance toward damaging wildlife in Africa (Naughton-Treves $\&$ Treves 2005) that were also present in our study site. These include scarce availability of land, losses absorbed by the household, low if any value of chillas to local people (in economic terms, see below), little alternate income (to replace the protein source lost) and highly-regulated coping strategies to face chillas (see below). The sum of those factors makes households highly vulnerable to chillas, and with little capacity to face poultry losses.

Utilitarian attitudes prevailed in farmers of Centinela as reported previously in the northern hemisphere (Kellert 1985, Conover 2002). Differences in attitudes toward different fox species and even toward the same species in 
TABLE 3

Responses to the questions used to measure attitudes on local farmers at Centinela, southern Chile $(n=43)$.

Respuestas a preguntas utilizadas para medir actitudes hacia el zorro chilla por parte de agricultores en la localidad de Centinela, Chile $(n=43)$.

\begin{tabular}{|c|c|c|c|}
\hline \multicolumn{4}{|c|}{ I would like chilla population in Centinela to... } \\
\hline $\begin{array}{l}\text {...disappear } \\
44.2 \%\end{array}$ & $\begin{array}{l}\text {..decrease } \\
25.6 \%\end{array}$ & $\begin{array}{c}\text {...be kept as they are } \\
7.0 \%\end{array}$ & $\begin{array}{l}\text {..increase } \\
23.3 \%\end{array}$ \\
\hline \multicolumn{4}{|l|}{ In regard to chillas ... } \\
\hline $\begin{array}{c}\text {...I do not like them at all } \\
39.5 \%\end{array}$ & $\begin{array}{c}\text {...I do not like them } \\
18.6 \%\end{array}$ & $\begin{array}{c}\ldots \mathrm{I} \text { am indifferent } \\
34.9 \%\end{array}$ & $\begin{array}{l}\text {...I like them } \\
7.0 \%\end{array}$ \\
\hline $\begin{array}{c}\text {...very damaging } \\
32.6 \%\end{array}$ & $\begin{array}{l}\ldots \text { damaging } \\
55.8 \%\end{array}$ & $\begin{array}{c}\text {..unimportant } \\
9.3 \%\end{array}$ & $\begin{array}{c}\text {...beneficial } \\
2.3 \%\end{array}$ \\
\hline
\end{tabular}

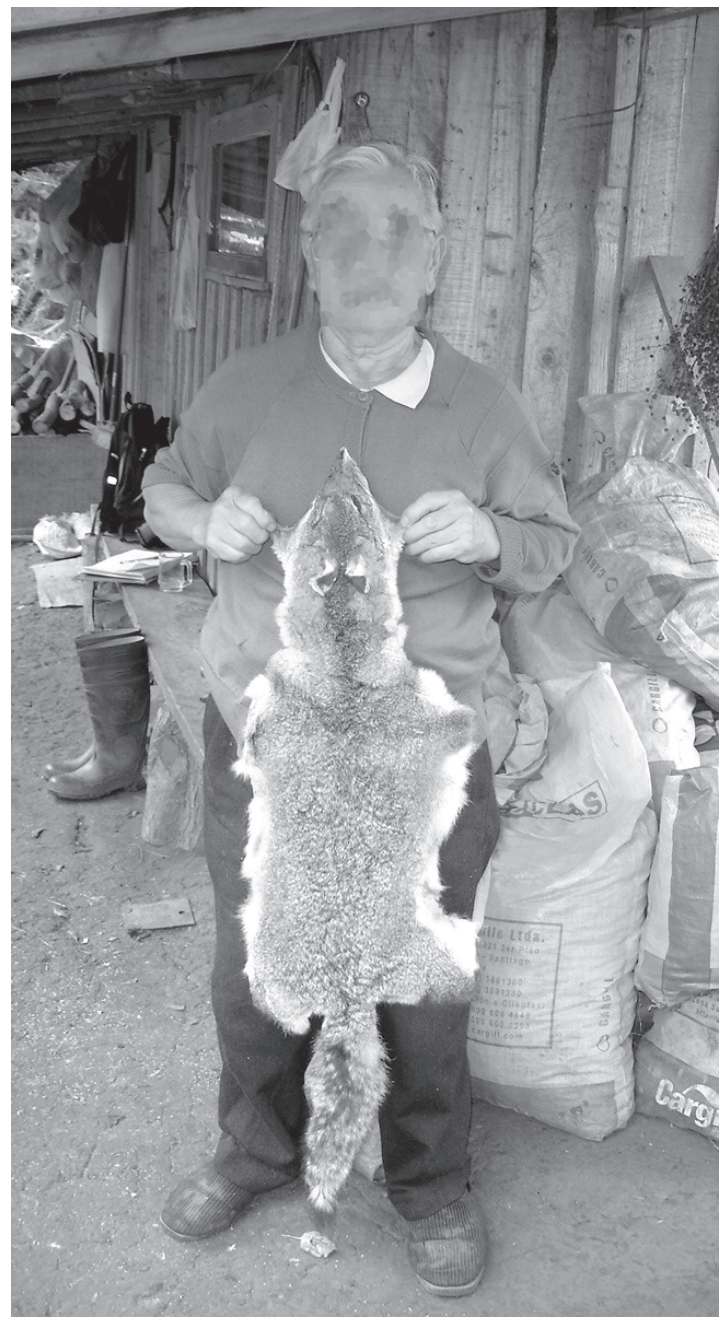

Fig. 3: Local farmer holding a pelt of a chilla killed. His face was distorted to protect his identity.

Agricultor local mostrando la piel de una chilla. Su cara fue difuminada para proteger su identidad. different places and contexts reflect the effect of utilitarian thinking among Latin-American farmers. For instance, it is likely that chillas -unlike culpeos- do not represent a major problem for sheep production in Patagonia (Novaro 1991), and consequently, attitudes were less negative for this species than for the culpeo among sheep rangers (Travaini et al. 2000). However, this distinction was not apparent in the high Andes of northwestern Argentina where negative attitudes and persecution of chillas (as well as culpeos and pumas) was prevalent (Lucherini \& Merino 2008). At Centinela, chillas were not perceived as an important problem for sheep. In fact no predation event was reported during our study, and it is likely that the single predation event reported for the last year corresponded to scavenging. In fact, during a parallel study we detected one chilla scat with sheep remains, but no owner claimed sheep losses. This supports the impression that the perceived predation of chillas on sheep could be related to scavenging or to predation on the doomed surplus. In spite of the lack of impacts on sheep, negative attitudes toward chillas were dominant among locals due to their impact on poultry. A similar scenario was reported for Sechura foxes (Lycalopex sechurae Thomas) in southern Perú (Cossios 2004). Interestingly, in Chiloé Island (southern Chile) most interviewees had never had experiences with the critically endangered Darwin's fox (Lycalopex fulvipes Martin) -neither negative nor positiveand positive attitudes dominated (Díaz 2005).

Older age and female gender were more associated with negative attitudes toward chillas, as was previously described by several authors 
for different carnivores (Bjerke et al. 2001, Ericsson \& Heberlein 2003, Kleiven et al. 2004, Kaltenborn et al. 2006). The importance of age on attitudes could be explained by the cumulative experience of the older people, who have had more chances to interact with foxes compared with younger people. Consequently, older people may have been affected by more predation events, as reported by Ericsson \& Heberlein (2003). Differences among gender could be explained because most of the labor related with poultry management -feeding, cleaning, and collection of eggs- are carried out by women, and consequently they were closest to the problem than men. Considering that chillas put the product of women's work at risk, stronger negative attitudes in women than men, as we found in this study, would be expected (Conover 2002, Kleiven et al. 2004).

Although our data is indeed limited by the extent of the study site and by the proximity of a city, our findings are likely to be common in rural areas of southern Chile. For example, the socio-economic profile of people in Centinela seems to fit well the general profile that defines the subsistence farmers of southern Chile (Amtmann et al. 1998). This suggests that similar attitudes and perceptions toward predators could be expected for other areas. This seems to be the case for guignas in Chiloé and Centinela (Sanderson et al. 2002, SilvaRodríguez et al. 2007). Similar scenarios regarding human perceptions toward foxes (and other carnivores) also seem to be frequent in central and northern Chile (C Bonacic et al., unpublished data) and in other areas of Latin America (Travaini et al. 2000, Cossios 2004, Lucherini \& Merino 2008).

\section{Foxes and poultry farming}

In Centinela, poultry losses were important, affecting 12 out of 37 families that had hens in a year. Each family lost an average of $34.5 \%$ of their hens. The value of a chicken in the local informal market was $\$ 1,500$ Chilean pesos (CLP) at the time of the study. Thus, the average cost of foxes for the farms that lose chickens was CLP $\$ 23,100$. This apparently small value represents about $2 \%$ of the annual income for people that live on a single pension (ca. CLP \$ 96,000, see http://www.safp.cl/573/ article-3799.html) or almost $24 \%$ of one month's income. Salaries around that amount or even lower were not uncommon in the area, especially among older people.

Poultry consumption by chillas in our study site was demonstrated through dietary analysis in a concurrent study, as chicken remains were found in $9 \%$ of 223 scats analyzed (SilvaRodríguez 2006). This has also been detected in other areas (Zúñiga et al. 2008) and in Centinela in a different season (EA SilvaRodríguez, unpublished data). The presence of chicken remains in chillas' scat provides independent evidence that chillas can and do prey on poultry. However, it does not provide quantitative information regarding the amount of losses suffered by the farmers. As a result, the real impact of foxes on poultry should be analyzed with caution, especially considering that it is based on retrospective estimations that are not supported by written records. Lack of records could have lead farmers to overestimate predator induced losses (Schaefer et al. 1981, Stahl et al. 2002), something that may have happened in our study site. Poultry predation by domestic dogs could also contribute to the overestimation of chilla damage. According to our interviews, poultry losses due to dogs were not detected by locals, but did actually occur, as we detected poultry remains in dogs' scats (EA Silva-Rodríguez, unpublished data). Thus predation by dogs on chicken may be subsidizing the bad reputation of chillas, as has been reported for wolves (Cozza et al. 1996).

There are also some common features between poultry-fox conflict at Centinela and previous reports from Europe. Poultry losses due to foxes happened outside henhouses and during the daytime, coinciding with data from France (Stahl et al. 2002). Consequently, continuous confinement of hens could easily solve the problem of daytime predation; however the high economic cost of fencing and netting, as well as having to feed the chickens makes this solution impractical for subsistence farmers such as those of Centinela. Night confinement of chicken in henhouses probably prevents higher losses when chillas are more active (Johnson \& Franklin 1994), and therefore serves as a compromise in terms of cost-benefit that otherwise could be catastrophic in terms of losses due to foxes. It seems that poultry-fox conflict is an important constraint only for non-commercial producers (see Heydon \& Reynolds 2000), because in 
commercial farms, losses due to foxes are relatively unimportant (Heydon \& Reynolds 2000, Stahl et al. 2002, Moberly et al. 2004). Moreover, commercial poultry is highly industrialized in Chile, with chickens permanently confined in intensive productive systems, making losses due to foxes extremely unlikely. Differences in hen numbers, coping ability and resources availability makes non commercial poultry and especially subsistence poultry producers more vulnerable than commercial poultry producers.

Culling of chillas appeared to be a popular measure used to prevent losses. However, although an important proportion of research participants had killed chillas at least once, few people admitted killing foxes during the last year (and just two killings were related to conflict). This suggests that active persecution of foxes either does not occur or is rare in the area, which contrasts with what has been reported in other areas (Lucherini \& Merino 2008). The fact that a high proportion of people recognized to have killed or persecuted foxes in the past suggest that the numbers reported for the last year may not be representative of the historical trend. An important factor that could have modified the behavior of people toward foxes is that the Chilean government modified the firearms law, requiring people to present the weapon registration when buying ammunitions (República de Chile 2005). People who had shotguns illegally could not employ the weapons against the chillas, which was frequently mentioned as a problem by locals. This new law, designed to prevent theft, appears to contribute to wildlife conservation. An alternative explanation for the low number of reports of intentional elimination of foxes could be that people were aware of the unlawfulness of killing foxes (República de Chile 2003) and thus hid information. This seems unlikely given the confidence with which some people expressed negative opinions regarding chillas and other carnivores, admitted to having killed foxes and other wild species (SilvaRodríguez et al. 2007, this study).

\section{Future directions}

Foxes prey on chicken, and the impacts of this predation can be socially significant, leading to negative attitudes among people. Chillas also prey on species that may harm farmers, such as mice and hares (Fig. 1), but this is not reflected in having better attitudes. Farmers' perceptions seems to reflect the extreme-damage events associated with chillas, rather than the persistent and small loses that cumulatively may be greater, such as mice action (NaughtonTreves 1997, Naughton-Treves \& Treves 2005). If this is the case, educating people on the role of foxes as pest controllers is unlikely to solve the problem if complementary strategies are not implemented.

In the case of Centinela, the problem seems easy to solve by keeping the chicken in their henhouses (most farmers already have them), and by guard them while released for foraging. While these solutions seem obvious, actions such as guarding the chickens while foraging will need to have support from the local community to be implemented. Such community involvement will be fundamental in any attempt to control humanwildlife conflicts given that people will need to change some behaviors and practices if they want to solve the problem (Treves et al. 2006). It could also be an alternative to consider compensation (for losses) or subsidies (e.g. food for chicken) to farmers when conflicts are affecting the viability of endangered species or populations. Future, research should attempt to quantify the actual impact of human-carnivore conflict on the viability of small-carnivores. This is likely to be an urgent need for species that are facing imminent extinction risk such as the case of the Darwin's fox.

\section{AKNOWLEDGEMENTS}

We thank local farmers for their cooperation, and N. Buhayar, S. Carlton, P. Feinsinger, G. Monti, R. Murúa, R. Schlatter, M. Sepúlveda, J.C. Skewes and two anonymous reviewers who provided valuable comments on the manuscript. This study was authorized by Servicio Agrícola y Ganadero (SAG) resolution number 6474 (22 November, 2005). During the writing of this manuscript E.A.S was supported by a Fulbright-Conicyt Fellowship.

\section{LITERATURE CITED}

AMTMANN CA, F MUJICA \& B VERA (eds) (1998) Pequeña agricultura en la Región de Los Lagos, Chile. Ediciones Universidad Austral de Chile, Valdivia, Chile. 300 pp. 
BABBIE ER (1988) Métodos de investigación por encuestas. Biblioteca de la Salud, México, D.F., México. 440 pp.

BJERKE T, BP KALTENBORN \& C THRANE (2001) Sociodemographic correlates of fear-related attitudes toward the wolf (Canis lupus lupus): A survey in southeastern Norway. Fauna Norvegica 21: 25-33.

CONOVER MR (2002) Resolving human-wildlife conflicts. Lewis Publishers, Florida, USA. 418 pp.

COSSIOS ED (2004) Relación entre el zorro de Sechura, Pseudalopex sechurae, y el hombre en el Perú. Ecología Aplicada 3: 134-138.

COZZA K, R FICO, ML BATTISTINI \& E ROGERS (1996) The damage-conservation interface illustrated by predation on domestic livestock in central Italy. Biological Conservation 78: 329-336.

DÍAZ VA (2005) Evaluación de la dimensión humana, a través del estudio de las actitudes y conocimientos de la gente de la Isla Grande de Chiloé, X Región, para futuros planes de conservación de fauna silvestre y su hábitat. Undergraduate Thesis, Facultad de Recursos Naturales, Universidad Católica de Temuco, Temuco, Chile. xiv +218 pp.

DICKMAN AJ (2005) An assessment of pastoralist attitudes and wildlife conflict in the Rungwa-Ruaha region, Tanzania, with particular reference to large carnivores. Master's Thesis, University of Oxford, Oxford, UK. 95 pp.

ERICSSON G \& TA HEBERLEIN (2003) Attitudes of hunters, locals, and the general public in Sweden now that the wolves are back. Biological Conservation 111: 149-159.

GINSBERG JR (2001) Setting priorities for carnivore conservation: What makes carnivores different? In: Gittleman JL, SM Funk, D MacDonald \& RK Wayne (eds) Carnivore conservation: 498-523. Cambridge University Press, Cambridge, UK.

GONZÁLEZ DEL SOLAR R \& J RAU (2004) Chilla, Pseudalopex griseus (Gray 1837). In: Sillero-Zubiri C, M Hoffmann \& DW MacDonald (eds) Canids: foxes, wolves, jackals and dogs: status survey and conservation action plan: 55-63. IUCN/SSC Canid Specialist Group, Gland, Switzerland.

GREER JK (1965) Mammals of Malleco Province, Chile. Publications of the Museum of Michigan State University, Biological Series 3: 49-152.

HEYDON MJ \& JC REYNOLDS (2000) Fox (Vulpes vulpes) management in three contrasting regions of Britain, in relation to agricultural and sporting interests. Journal of Zoology 251: 237-252.

HOUSSE R (1953) Animales salvajes de Chile en su clasificación moderna. Ediciones de la Universidad de Chile, Santiago, Chile. 189 pp.

INSKIP C \& A ZIMMERMANN (2009) Human-felid conflict: a review of patterns and priorities worldwide. Oryx 43: 18-34.

JIMÉNEZ JE, JL YÁÑEZ, EL TABILO \& FM JAKSIC (1995) Body-size of Chilean foxes - a new pattern in light of new data. Acta Theriologica 40: 321-326.

JOHNSON WE \& WL FRANKLIN (1994) Conservation implications of the South American gray fox (Dusicyon griseus) socioecology in the Patagonia of Southern Chile. Vida Silvestre Neotropical 3: 16-23.

KALTENBORN BP, T BJERKE, JW NYAHONGO \& DR WILLIAMS (2006) Animal preferences and acceptability of wildlife management actions around Serengeti National Park, Tanzania. Biodiversity and Conservation 15: 4633-4649.

KELLERT SR (1985) Public perceptions of predators, particularly the wolf and coyote. Biological Conservation 31: 167-189.

KLEIVEN J, T BJERKE \& BP KALTENBORN (2004) Factors influencing the social acceptability of large carnivore behaviours. Biodiversity and Conservation 13: 1647-1658.

LUCHERINI M \& MJ MERINO (2008) Perceptions of human-carnivore conflicts in the High Andes of Argentina. Mountain Research and Development 28: 81-85.

LUEBERT F \& P PLISCOFF (2005) Bioclimas de la cordillera de la costa del centro-sur de Chile. In: Smith-Ramírez C, JJ Armesto \& C Valdovinos (eds) Historia, biodiversidad y ecología de los bosques costeros de Chile: 60-72. Editorial Universitaria, Santiago, Chile.

MOBERLY RL, PCL WHITE \& S HARRIS (2004) Mortality due to fox predation in free-range poultry flocks in Britain. Veterinary Record 155: 48-52.

NAUGHTON-TREVES L (1997) Farming the forest edge: vulnerable places and people around Kibale National Park, Uganda. Geographical Review 87: 27-46.

NAUGHTON-TREVES L \& A TREVES (2005) Socioecological factors shaping local support for wildlife: crop-raiding by elephants and other wildlife in Africa. In: Woodroffe R, S Thirgood \& A Rabinowitz (eds) People and wildlife: conflict or coexistence?: 252-277. Cambridge University Press, Cambridge, UK

NOVARO AJ (1991) Feeding ecology and abundance of a harvested population of culpeo fox (Dusicyon culpaeus) in Patagonia. Master's Thesis, University of Florida, Gainesville, Florida, USA. 103 pp.

REPÚBLICA DE CHILE (2003) Reglamento de la Ley de Caza. Decreto Supremo No 5 de enero de 1998. Ministerio de Agricultura, Santiago, Chile. 45 pp

REPÚBLICA DE CHILE (2005) Ley $\mathrm{N}^{\circ}$ 20.014: modifica la Ley $\mathrm{N}^{\circ} 17.798$, sobre control de armas. Ministerio del Interior, Santiago, Chile. $11 \mathrm{pp}$.

SANDERSON J, ME SUNQUIST \& AW IRIARTE (2002) Natural history and landscape-use of guignas (Oncifelis guigna) on Isla Grande de Chiloe, Chile. Journal of Mammalogy 83: 608-613.

SCHAEFER JM, RD ANDREWS \& JJ DINSMORE (1981) An assessment of coyote and dog predation on sheep in southern Iowa. Journal of Wildlife Management 45: 883-893.

SILLERO-ZUBIRI C \& MK LAURENSON (2001) Interactions between carnivores and local communities: conflict or coexistence? In: Gittleman JL, SM Funk, D MacDonald \& RK Wayne (eds) Carnivore conservation: 282-312. Cambridge University Press, Cambridge, UK.

SILLERO-ZUBIRI C \& D SWITZER (2004) Management of wild canids in human dominated landscapes. In: Sillero-Zubiri C, M Hoffmann \& DW MacDonald (eds) Canids: foxes, wolves, jackals and dogs: status survey and conservation action plan: 257266. IUCN/SSC Canid Specialist Group, Gland, Switzerland.

SILVA-RODRÍGUEZ EA (2006) Evaluación de conflictos entre zorros chillas (Pseudalopex griseus) y agricultura de subsistencia en una localidad rural del sur de Chile: ¿mito o realidad? Veterinary Medicine Thesis, Facultad de Ciencias Veterinarias, Universidad Austral de Chile, Valdivia, Chile. 87 pp.

SILVA-RODRÍGUEZ EA, GR ORTEGA-SOLÍS \& JE JIMÉNEZ (2007) Human attitudes toward wild felids in a human-dominated landscape of southern Chile. Cat News 46: 19-21. 
STAHL P, S RUETTE \& L GROS (2002) Predation on free-ranging poultry by mammalian and avian predators: field loss estimates in a French rural area. Mammal Review 32: 227-234.

TRAVAINI A, SC ZAPATA, R MARTÍNEZ-PECK \& M DELIBES (2000) Percepción y actitud humanas hacia la predación de ganado ovino por el zorro colorado (Pseudalopex culpaeus) en Santa Cruz, Patagonia Argentina. Mastozoología Neotropical 7: 117-129.

TREVES A \& KU KARANTH (2003) Human-carnivore conflict and perspectives on carnivore management worldwide. Conservation Biology 17: 1491-1499.
TREVES A, RB WALLACE, L NAUGHTON-TREVES \& A MORALES (2006) Co-managing human-wildlife conflicts: A review. Human Dimensions of Wildlife 11: 383-396.

WOODROFFE R, S THIRGOOD \& A RABINOWITZ (2005) The impact of human-wildlife conflict on natural systems. In: Woodroffe R, S Thirgood \& A Rabinowitz (eds) People and wildlife: conflict or coexistence?: 112. Cambridge University Press, Cambridge, UK.

ZÚÑIGA A, A MUÑOZ-PEDREROS \& A FIERRO (2008) Dieta de Lycalopex griseus (Gray, 1837) (Mammalia: Canidae) en la depresión intermedia del sur de Chile. Gayana 72: 113-116.

Associate Editor: Peter Feinsinger

Received October 2, 2008; accepted July 10, 2009

APPENDIX

QUESTIONNAIRE: SUBSISTENCE FARMING AND CHILLA FOXES: LOCAL KNOWLEDGE, BELIEFS AND ATTITUDES

Note: the version in Spanish can be found in SILVA-RODRÍGUEZ (2006)

\section{General information}

1. Gender

2. Age

3. Years in school: a) None; b) $\leq 8$ years; c) 9-12 years; d) $>12$ years

5. Time living in Centinela

6. Area of property

7. Type of property tenure: a) Own; b) Lease; c) Informal tenancy; d) Lent by employer; e) Other

8. How many people live in your house?

9. Please list the production activities carried out on your property

10. What are the principal sources of income for your family?

\section{Management of domestic animals}

11. If you own livestock, fowl or other domestic animals:

a) What kinds?

What is your reason for having them? (formal commerce, informal commerce, auto-consumption, investment for the future, others)

b) How do you manage your livestock/fowl? (Free range 24 hours, nocturnal confinement, permanent confinement)

c) What do you think are the best methods to protect your livestock/fowl from potential predators?

d) Which of those methods do you apply?

e) Why?

\section{Opinions about foxes}

21. Please indicate which of the following statements best expresses your desires with respect to populations of foxes in Centinela during the coming years: I would like them a) to disappear; b) to decrease; c) to remain as they are; d) to increase somewhat; e) to increase substantially.

22. Please indicate which of the following statements best expresses your feelings about the foxes: a) I dislike them intensely; b) I dislike them; c) I am indifferent; d) I like them; e) I like them a lot.

23. Please indicate which of the following statements best expresses your opinion about foxes in relation to the activities on your farm: foxes are a) very damaging; b) damaging; c) unimportant; d) beneficial; e) highly beneficial.

24. Have you ever hunted/trapped foxes? How?

25. What is the main item in foxes' diet? (Give just one answer)

26. Please mention other items that foxes eat.

27. During the past year how many foxes did you hunt? (intentionally or accidentally)

28. What was the reason that motivated you to hunt it/ them?

29. If you lost livestock/fowl to foxes during the last year please answer the following questions: a) which livestock/fowl were affected? b) How many livestock/ fowl did you lose? c) How many livestock/fowl did you have prior to the losses?

30. In which season are losses due to foxes most frequent?

31. Have you ever seen a fox eating or hunting a domestic fowl?

32. Please indicate which of the following statements best expresses the typical pattern of fox-induced poultry losses: Foxes a) hunt one bird and do not return; b) hunt one bird and return later for more; c) hunt many birds at once, but do not return; d) hunt many birds at once, and return later for more.

33. Regarding the hunting of foxes: a) It is permitted by law; b) foxes can be hunted but only when they kill livestock or fowl; c) It is forbidden by law; d) I do not know. 